Southern Illinois University Carbondale

OpenSIUC

Articles

Department of Plant, Soil, and Agricultural Systems

Summer 7-31-2017

\title{
Evaluation of the antimicrobial activities of ultrasonicated spinach leaf extracts using RAPD markers and electron microscopy
}

Ammar Badran Altemimi

Southern Illinois University Carbondale

Naoufal Lakhssassi

Southern Illinois University Carbondale, naoufal.lakhssassi@siu.edu

Amer Abughazaleh

Southern Illinois University Carbondale

David Lightfoot

Southern Illinois University Carbondale

Follow this and additional works at: http://opensiuc.lib.siu.edu/psas_articles

\section{Recommended Citation}

Altemimi, Ammar B., Lakhssassi, Naoufal, Abughazaleh, Amer and Lightfoot, David. "Evaluation of the antimicrobial activities of ultrasonicated spinach leaf extracts using RAPD markers and electron microscopy." Archives of Microbiology 017 (Summer 2017): 1418-6. doi:10.1007/s00203-017-1418-6.

This Article is brought to you for free and open access by the Department of Plant, Soil, and Agricultural Systems at OpenSIUC. It has been accepted for inclusion in Articles by an authorized administrator of OpenSIUC. For more information, please contact opensiuc@lib.siu.edu. 


\title{
Evaluation of the antimicrobial activities of ultrasonicated spinach leaf extracts using RAPD markers and electron microscopy
}

\author{
Ammar Altemimi ${ }^{1,2,4}$, Naoufal Lakhssassi ${ }^{1,4^{*}}$, Amer Abu-Ghazaleh ${ }^{3}$, David A. Lightfoot ${ }^{1}$ \\ ${ }^{1}$ Department of Plant, Soil and Agricultural Systems, Southern Illinois University, Carbondale, \\ IL 62901, USA. '2Department of Food Science, College of Agriculture, University of Basrah, Al- \\ Basrah 61004, IRAQ. ${ }^{3}$ Department of Animal Science Food and Nutrition, Southern Illinois \\ University, Carbondale, IL 62901, USA. *Author to whom correspondence should be addressed; \\ E-Mail: naoufal.lakhssassi@siu.edu; Tel.: +1-618-453-2606. ${ }^{4}$ These authors contribute equally \\ to this work.
}


Spinach (Spinacia oleracea L.) leaves represent an important dietary source of nutrients, antioxidants, and antimicrobials. As such, spinach leaves play an important role in health and 29 have been used in the treatment of human diseases since ancient times. Here the aims were to optimize the extraction methods for recovering antimicrobial substances of spinach leaves, 31 determine the minimum inhibitory concentrations (MICs) of the antimicrobial substances against 32 Escherichia coli and Staphylococcus aureus and finally, evaluate the effects of spinach leaves' 33 antimicrobials on bacterial DNA using central composite face centered methods (CCFC). The 34 effect of the extracts on both Gram positive and Gram negative bacterial models were examined 35 by scanning electron microscopy (SEM) and random amplification of polymorphic (bacterial) DNA (RAPD). The optimal extraction conditions were at $45^{\circ} \mathrm{C}$, ultrasound power of $44 \%$ and an extraction time of $23 \mathrm{~min}$. The spinach extracts exhibited antimicrobial activities against both bacteria with MICs in the $60-100 \mathrm{mg} / \mathrm{ml}$ range. Interestingly, SEM showed that treated bacterial cells appear damaged with a reduction in cell number. RAPD analysis of genomic DNA showed that the number and sizes of amplicons were decreased by treatments. Based on these results, it was inferred that spinach leaves extracts exerts bactericidal activities by both inducing mutations

42 in DNA and by causing cell wall disruptions.

Keywords: Spinach; antimicrobial activity; SEM; RAPD; Ultrasonic extraction; Escherichia coli; bacterial pathogens; Staphylococcus aureus.

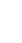

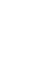

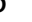

7




\section{Introduction}

In the past few decades, there has been a significant increase in resistance to antibiotics of many pathogenic bacteria (Chopra et al. 1996). For instance, approximately 90-95\% of Staphylococcus aureus strains were reported to be resistant to penicillin (Casal et al. 2005), and around 70-80\% were methicillin-resistant (Chambers 2001). Most antibiotics face resistance from other bacteria, including strains of Escherichia coli (Diemert 2006). Thus, antibiotics are becoming ineffective treatments to control the diseases caused by these bacteria. The antibiotic resistance is a global problem and antibiotic-resistant bacterial strains are increasingly appearing around the world, making the discovery of new agents with antimicrobial activities very important. A large variety of plants contain antimicrobial substances and may be used to develop new therapies against antibiotic-resistant microbial strains (Miyasaki et al. 2010).

A great number of natural plant products have been used as traditional medicines against bacterial pathogens (Rojas et al. 2006). In addition to essential nutrients, plants contain a variety of antioxidants and antimicrobial compounds. Tajkarimi and coworkers (Tajkarimi et al. 2010) reported that there are more than 1,340 plants, which contain compounds with antimicrobial activities and to date scientists have isolated more than 30,000 antimicrobial compounds from plants. Leafy vegetables such as spinach are valuable because they contain many bioactive compounds including proteins, peptides, phenolics, tannins, saponins, cyanogenic-glycosides, terpenoids, alkaloids, steroids and defensins (Adeniran et al. 2013). Phytochemical screening of tree spinach (Cnidoscolus aconitifolius (Miller) Johnston) leaves confirmed the presence of secondary metabolites that inhibited E. coli and Bacillus subtilis growth (Adeniran et al. 2013). Other studies have shown that plant polyphenols are natural alternatives to synthetic antimicrobial and antioxidant agents (Xi and Shouqin 2007).

Spinach leaves contain defensins, which exhibit antimicrobial activities (Stotz et al. 2009). Defensins are one class among the many types of Cys-rich antimicrobial peptides. Plant defensins differ in length (45-54 residues) and folding patterns. Plant defensins have been divided into three groups based on their antimicrobial activities. The first group of defensins can inhibit both bacteria and fungi, while the second group of defensins can prevent the growth of fungi but are inactive toward bacteria. The third group deters insect feeding by inhibiting 
amylases and proteinases. These defensins were found to prevent the growth of both Gram positive bacteria and Gram negative bacteria but were inactive toward fungi (Broekaert et al. 1995). Moreover, Segure et al. (1998) identified a new group of defensins from spinach leaves (Spinacia oleracea L.), which are active against fungi, as well as Gram-positive and Gramnegative bacteria. Two of these defensins (SoD2 and SoD7) are used to protect citrus fruit crops. Defensins are classified as PR12s. In fact, plants like spinach produce many other compounds with broad anti-microbial properties, which are categorized into 17 activity classes (PR1-17) (Bai et al.2014). The PR1, PR4, and PR5 class proteins have mainly broad antifungal activities, however, most of the rest of the other classes were inhibitors of pathogen enzyme activities (Tegos et al. 2002).

Preferences for the use of natural antioxidants and antimicrobial agents over synthetic compounds has increased within food industries worldwide (Han and Seo 2002; Vickers 2002). Many people depend on medicinal plants in developing countries (El-Shemy et al. 2007) and their use in diets is common (Prior and Cao 2000). Drug-resistant skin pathogens like methicillin-resistant S. aureus (Marathe et al. 2013) can be inhibited by plant extracts. Other common foodborne bacteria like E. coli serotype O157:H7 might also be sensitive to plantderived phenolics (Diemert 2006). Many studies have shown that consuming diets containing a low amount of vegetables is associated with an increased risk of cancer (Prior and Cao 2000). Conversely, consuming diets rich in fruits and vegetables, containing antioxidants, lowers the incidence of cancer. Due to increased awareness of the health benefits that strongly pigmented vegetables provide, a colorful diet has created new markets for heritage cultivars, specifically developed for their health benefits. Studies of plant extracts have shown that flavonoids (orange/yellow pigments), anthocyanins (red pigments), and general phenolics (colorless) are good sources of antioxidants in addition to having antimicrobial properties (Marathe et al. 2013; Yolmeh et al. 2014). Further, extracts were active against various human pathological conditions such as inflammation, cancer, atherosclerosis, and even circulatory problems (Cevallos-Casals et al. 2006; Gil et al. 2002; Prior and Cao 2000).

To partially purify bioactive components from plants, a number of extraction techniques that have been developed including ultrasound-assisted extraction (UAE), supercritical fluid extraction, enzymatic extraction, and Soxhlet extraction (Pedersen and Olsson 2003; Vinatoru 
2001). Among these, UAE was found to be an inexpensive, simple, and efficient extraction technique. The benefits of using ultrasound are mainly attributed to the effect of acoustic cavitation of plant tissue produced by the solvent (Ghafoor et al. 2009). Ultrasound also creates a mechanical effect that allows greater penetration of solvents into the tissues, increasing the contact surface area between the solid and liquid phase (Pedersen and Olsson 2003; Vinatoru 2001).

Screening of plant extracts is a promising approach to find new compounds with the capability of eliminating pathogenic bacteria. Spinach (S. oleracea L.) extracts made by UAE were reported to contain effective antioxidants (Altemimi et al. 2015a) and it was proposed that the extracts might be active against foodborne pathogens. In the present study, UAE and BoxWilson designs were used in order to optimize the protocol for extracting antimicrobial activities from spinach. Antimicrobial activities of prepared spinach extracts were tested for the ability to inhibit the growth of Gram-negative and Gram-positive bacteria.

\section{Materials and methods}

\section{Preparation of plant material}

Spinach (cv. 'Tyee') was grown at the Horticulture Research Center of Southern Illinois University according to common commercial practices (Altemimi et al. 2015a; Altemimi et al. 2015c). Fresh spinach (cv. Tyee) leaves were harvested from randomly selected mature plants, at 45 days after planting then washed, sliced into small pieces, and stored at $-18^{\circ} \mathrm{C}$. Five days later samples were freeze-dried.

\section{Ultrasonic-assisted extraction (UAE) of spinach leaves}

An Elmasonic P30 (P30) ultrasonic cleaner (Elma Hans Schmidbauer GMBH, Singen, Germany) was coupled with controlled heating using a cooling coil (Fisher Scientific Inc. St Louis USA); connected with a cooling chiller water bath; and a water pump (Model HJ-111, submersible pump, flow rate $250 \mathrm{~L} / \mathrm{h}$, Sunsun Inc., Zhejiang, China). Coupled heating and cooling helped maintain evenly distributed temperatures across the ultrasonic water bath. Extracts were made at $37^{\circ} \mathrm{C}$ and $80 \mathrm{kHz}$ frequencies with three heated bath temperatures, and 
three power settings expressed as a percentage of full power (30-100\%). The standard ultrasonic mode was used. Temperature settings used for this study were $30^{\circ} \mathrm{C}, 40^{\circ} \mathrm{C}$, and $50^{\circ} \mathrm{C}$ and power level settings were $30 \%, 50 \%$ and $70 \%$. The manufacturer rated the P30 with an ultrasonic peak power of $480 \mathrm{~W}$ and an effective power rating of $120 \mathrm{~W}$. The P30 had a proprietary algorithm for adjusting power based on the impedance of the system. For a specific power setting, samples were subjected to the same degree of cavitation regardless of the load in the tank. For all treatments, the bath of the P30 contained $1.7 \mathrm{~L}$ of water before the treatment containers were added. Ultrasonic power was expressed as $\mathrm{W} / \mathrm{cm}^{2}$, based on the power setting as a percentage of rated power and the volume of the bath solution prior to addition of the treatment containers. Ultrasonic peak powers for the $30 \%, 50 \%$ and $70 \%$ power settings were $85 \mathrm{~W} / \mathrm{cm}^{2}, 141 \mathrm{~W} / \mathrm{cm}^{2}$ and $198 \mathrm{~W} / \mathrm{cm}^{2}$, respectively. The effective power inside the extract containers was $21 \mathrm{~W} / \mathrm{cm}^{2}$, $35 \mathrm{~W} / \mathrm{cm}^{2}$, and $49 \mathrm{~W} / \mathrm{cm}^{2}$ respectively.

Ten grams of lyophilized spinach were mixed with $100 \mathrm{ml}$ of methanol, and then added in $200 \mathrm{ml}$ flasks and the samples were subject to UAE in an ultrasonic water bath (Elmasonic P30). After the samples were exposed to ultrasound waves, the mixture was filtered using filter paper (Whatman ${ }^{\mathrm{TM}}$ no.1). The solids were re-extracted in fresh methanol to ensure the effective extraction of all bioactive compounds. Finally, the solvent was removed with a rotary evaporator under vacuum at $40^{\circ} \mathrm{C}$.

\section{Microorganisms and growth conditions}

The microorganisms used in this study were S. aureus (ATCC 29213) and E. coli OH157:H7 (ATCC 25922). Microbial cultures were grown in nutrient broth (NB) for 24 hours before testing.

Bacterial strains were grown on both Muller-Hinton agar and nutrient broth. Both were sterilized by autoclaving at $121^{\circ} \mathrm{C}$ for $15 \mathrm{~min}$ (Sterileforge, Market Forge, MA, USA). The nutrient broth was used to grow bacteria while Muller-Hinton agar was used to maintain the cultures used in this study and to create lawn plates for testing the spinach extracts. Before measuring the antimicrobial activities of crude extracts, the bacteria were grown to a midlogarithmic stage of growth. They were moved by a loop to fresh test tubes containing NB and 
grown, with aeration, to an $\mathrm{OD}_{600}$ of 0.6 (Singh et al. 2013). Suspensions of the bacteria, adjusted by serial dilutions to final cell concentrations $10^{-6} \mathrm{CFU} / \mathrm{ml}$, were added to flasks containing 25 $\mathrm{ml}$ Muller-Hinton agar at $43-45^{\circ} \mathrm{C}$, and poured into petri plates.

\section{Disk diffusion assay}

Plant extracts were used for the disc diffusion method to determine their relative antimicrobial activity at different concentrations against bacterial cultures of $E$. coli and $S$. aureus (Bauer et al. 1966). Antibiotic discs of streptomycin were used as positive controls, while blank discs were used as negative controls. To test plant extracts, sterile blank discs (Becton, Dickinson and Company, Sparks, MD, USA) were saturated with $40 \mu$ of extracts at a concentration of $140 \mathrm{mg} / \mathrm{ml}$. The soaked discs and antibiotic discs were placed on plates and incubated at $37^{\circ} \mathrm{C}$ for $18-24 \mathrm{~h}$ in the inverted position (Sağdıç et al. 2002; Sağdıç and Özcan 2003). At the end of the incubation period, diameters of the inhibition zone were measured using a compass (Burt 2004; Faleiro et al. 1999; Shan et al. 2007).

\section{Determination of Minimum Inhibitory Concentration (MIC)}

To measure the MIC values, various concentrations of the optimized spinach leaf extracts $(2.5-100) \mathrm{mg} / \mathrm{ml}$ were assayed against the test bacteria. In each well of the 96 well plates, $100 \mu \mathrm{l}$ of plant extracts and $5 \mu \mathrm{l}$ of the bacterial solution (at $10^{6} \mathrm{CFU} / \mathrm{ml}$ ) were added. The plates were incubated at $37^{\circ} \mathrm{C}$ under aerobic conditions for $24-48 \mathrm{~h}$, after which $40 \mu \mathrm{l}$ of p-iodo-nitrotetrazolium violet salts solution (INT) were added to each well (to a final of $0.2 \mathrm{mg} / \mathrm{ml} \mathrm{INT}$ ). Plates were incubated at $37^{\circ} \mathrm{C}$ for $30-60$ minutes. The salt solution of INT serves as an electron acceptor and indicates the biological activity in the tested samples. The presence of color in the salt solution indicates microbiological activity in the tested samples, while the lack of color indicates a lack of microbiological activity (Eloff 1998).

\section{Scanning electron microscopy (SEM)}

For examination by scanning electron microscopy (SEM), small pieces of agar from the inhibition zone of treated and control samples were cut and fixed in $2.5 \%(\mathrm{v} / \mathrm{v})$ glutaraldehyde buffered with $0.1 \mathrm{M}$ sodium phosphate buffer $(\mathrm{pH}$ 7.2) for 1-2 hours at room temperature. 
Samples were then rinsed three times (30 min intervals) with sodium phosphate buffer and postfixed using $2 \%(\mathrm{w} / \mathrm{v})$ osmium tetroxide $\left(\mathrm{OsO}_{4}\right)$. After post-fixation samples were rinsed three times with distilled water (at 30 min intervals) and subjected to serial dehydration through graded alcohol $(25,50,75$ and 100\% (v/v)). Finally, the samples were dehydrated by critical point drying and placed on the silver stub for SEM imaging (gold sputter coated). The samples were analyzed in Quanta 450 FEG Scanning Electron Microscope (20kV, WD 10mm).

\section{Isolation of bacterial DNA}

In order to extract bacterial DNA, the bacteria were grown in LB medium (in presence of leaf extracts at $140 \mathrm{mg}$ solids) at $37^{\circ} \mathrm{C}$ in a $15 \mathrm{ml}$ tube placed in an incubator shaker (New Brunswick, MA, USA) set at $200 \mathrm{rpm}$ overnight. Controls containing untreated bacteria were grown in LB medium only. Cells were harvested by centrifugation at 13,000 $g$ for 10 min and washed once with $0.85 \%(\mathrm{w} / \mathrm{v}) \mathrm{NaCl}$ before chromosomal DNA isolation. Bacterial DNA was obtained using the Wizard ${ }^{\mathrm{TM}}$ Genomic DNA purification kit (Promega, Madison, WI, USA).

\section{Random amplification of polymorphic DNA (RAPD) analysis of the genomic DNA}

DNA fingerprinting of bacterial genomic DNA using random amplification of polymorphic DNA (RAPD) technique is a modification of the polymerase chain reaction (PCR), which utilizes a single, arbitrarily-chosen primer to amplify a number of fragments from a given DNA template to generate a discrete fingerprint when resolved by gel electrophoresis. Many primers suitable for this approach were reported. Single base alterations due to mutations in the genomic template DNA lead to changes in the RAPD fingerprints. Three random primers OPA05 (5`-AGGGGTCTTG-3`), OPA-06 (5`- GGTCCCTGAC-3`) and OPB-06 (5`TGCTCTGCCC-3`), were used for RAPD fingerprinting of the treated and non-treated two bacterial isolates. These primers were used previously (Williams et al. 1990) for RAPD analysis of gram positive and negative bacterial DNA. The PCR amplification for RAPD reactions was performed in a $20 \mu \mathrm{l}$ reaction mixture (Go-Taq ${ }^{\mathrm{TM}}$ polymerase, Promega, USA). The temperature profile was as follows; an initial denaturation step at $94^{\circ} \mathrm{C}$ for $4 \mathrm{~min}, 35$ cycles of denaturation at $94^{\circ} \mathrm{C}$ for $1 \mathrm{~min}$, then annealing at $34^{\circ} \mathrm{C}$ for $1 \mathrm{~min}$ and extension at $72^{\circ} \mathrm{C}$ for $2 \mathrm{~min}$. Finally, extension at $72^{\circ} \mathrm{C}$ for 7 min was executed. PCR products were separated by electrophoresis in a 
$1 \%(\mathrm{w} / \mathrm{v})$ agarose gel, stained with ethidium bromide and photographed using a BioSpectrum AC Imaging System (UVP, Upland, CA, USA). The RAPD markers were used to generate amplicons from genomic DNA of both treated and untreated bacteria. The number of polymorphisms was compared after treatment with spinach leave extracts or just plain water.

\section{Experimental design}

A Box-Wilson central composite design (CCD) was used to monitor and control the number of experiments (Yang et al. 2009). In this study, the central composite face centered (CCFC) experimental design in CCD was conducted to infer the optimal states of independent variables (extraction temperature ( $(\mathrm{C})$, power of ultrasound (W), and extraction time (min)) on the traits (zones of inhibition of ultrasound-assisted spinach leaf extracts). According to the preliminary results, the independent variables and their ranges were assigned to be extraction temperature $\left(30-50{ }^{\circ} \mathrm{C}\right)$, power of ultrasound $(30-70 \%)$, and extraction time (10-30 min). After that, the experiments were based on the central composite face centered (CCFC) experimental design with three factors at three levels (Maran et al. 2013a).

The complete design was carried out in a random order and consisted of 20 combinations including three replicates (Table 1). The data from the experimental design were analyzed by multiple regressions to fit the following quadratic polynomial model:

$Y=b_{0} \sum_{i=1}^{3} b_{i} X_{i}+\sum_{i=1}^{3} b_{\mathrm{ii}} X_{i}^{2}+\sum_{i \neq j=1}^{3} b_{\mathrm{ii}} X_{i} X_{j}$

In this model $\mathrm{Y}$ is the predicted response; $\mathrm{b}_{0}$ is the intercept; $\mathrm{b}_{1}, \mathrm{~b}_{2}$ and $\mathrm{b}_{3}$ are the linear coefficients of temperature $\left(\mathrm{X}_{1}\right)$, power $\left(\mathrm{X}_{2}\right)$ and time $\left(\mathrm{X}_{3}\right)$, respectively; $\mathrm{b}_{11}, \mathrm{~b}_{22}$ and $\mathrm{b}_{33}$ are the squared coefficients of temperature of sonication, power and time respectively; $b_{12}, b_{13}$ and $b_{23}$ are the interaction coefficients of temperature, power and time of sonication respectively. Finally, the levels of the independent variables were represented as $X_{i}$ and $X_{j}$.

\section{Statistical analysis}


All experiments were conducted in triplicates and data were analyzed using one-way ANOVA procedures of the SAS software. Means were declared significantly different at $P<$ 0.05 .

\section{Results and Discussion}

\section{CCFC and developed second order polynomial models}

A total of 20 experiments, including six center points (used to determine the experimental error), were carried out in order to determine the optimal extraction conditions of spinach leaves that yield a maximal antimicrobial activity. The various combinations of experimental conditions (coded and uncoded) with their respective experimental responses are presented in Table 2.

In order to test three degrees of polynomial models, the experimental data were analyzed. Two statistical tests were focused upon; the sequential model sum of squares; and the model summary statistics. These two tests were conducted in order to test the adequacy of models to determine the antimicrobial activities of spinach leaf extracts (Table 2). The output of the adequacy of tested models was not dependent on a single factor. For instance, $\mathrm{R}^{2}$, and $\mathrm{p}$ values were important to select an adequate model. The results showed that a quadratic model was not appropriate regardless of having a low p-value (0.0244). The linear model also had a high pvalue ( $>0.05$ ), low values of $\mathrm{R}^{2}$ and adjusted $\mathrm{R}^{2}$ (Table 2 ). Therefore, both the linear and cubic models were deemed inappropriate for further modeling of this experimental data. Therefore, the quadratic model was selected for further analysis.

Developing mathematical models depended on fitting models of the second-order polynomial equation with interaction terms. This helped increase the predictive values of an extraction efficiency of different sets of combinations of three process variables on the responses. In this study, two equations were developed to predict the UAE efficiency of antimicrobial activity from spinach leave extracts. The model finally inferred is given below:

Zone of inhibition for $S$. aureus $=+24.67+1.80 * \mathrm{X}_{1}-0.60 * \mathrm{X}_{2}+0.70 * \mathrm{X}_{3}-0.37 * \mathrm{X}_{1} \mathrm{X}_{2}-$ $0.37 * \mathrm{X} 1 \mathrm{X} 3+0.12 * \mathrm{X} 2 \mathrm{X} 3-1.18 * \mathrm{X}_{1}^{2}-2.18 \mathrm{X}_{2}^{2}-1.688 \mathrm{X}_{3}^{2}$ 
270

271

272

273

274

275

276

277

Zone of inhibition for $E$. coli $=+20.64+1.70 * \mathrm{X}_{1}-0.65 * \mathrm{X}_{2}+0.75 * \mathrm{X}_{3}-0.31 * \mathrm{X}_{1} \mathrm{X}_{2}-$ $0.44 * \mathrm{X}_{1} \mathrm{X}_{3}+0.062 * \mathrm{X}_{2} \mathrm{X}_{3}-0.98 * \mathrm{X}_{1}^{2}-2.238 \mathrm{X}_{2}^{2}-1.73 \mathrm{X}_{3}^{2}$

In order to examine the models, multiple regression and ANOVA were used (Table 3). According to Ghafoor et al. (2009), a positive value prefers the optimization due to a synergistic effect, while a negative value exhibits an inverse relationship or antagonistic effect between the factor and the response. According to the ANOVA table, the models were highly significant for all the responses at a $\mathrm{p}<0.0001$ with F-values of 22.05 and 20.13 for $S$. aureus and E. coli, respectively.

\section{Studies of the effects of process variables}

Here, three factors at three levels of the CCFC design were used to study the influence of process variables (extraction temperature, power of ultrasound, and extraction time) on antimicrobial activity of spinach leaf extracts. The models were used to construct three dimensional response surfaces and contour plots. The main and interactive effects of independent variables on a response variable were associated with graphical representations of a regression equation. The graphs were made by maintaining one factors constant (the central levels) and varying the other two factors in order to understand their main and interactive effects on the dependent variables (Maran et al. 2013b).

\section{Effects of extraction temperatures}

The effects of extraction temperatures on the antimicrobial activity of spinach leaf extracts showed that there was both a positive linear and cubic effect of ultrasonic extraction temperatures (Table 3) on the inhibitory zone diameters for S. aureus and E. coli. When the temperature was increased from 30 to $45^{\circ} \mathrm{C}$, the inhibitory zone diameters (Fig. $1 \&$ Fig. 2) were $24.95 \pm 0.10 \mathrm{~mm}$ and $20.93 \pm 0.13 \mathrm{~mm}$ according to optimization condition for $S$. aureus and $E$. coli, respectively. However, it appears that the negative effects of higher temperatures were due to decreased antimicrobial activities in the spinach leaf extracts. This finding was in agreement with previous studies by Altemimi et al. (2015b) in which it was shown that increasing extraction temperatures caused the loss of anti-oxidant activities and lower concentrations of lutein and $\beta$ carotene. 
The antimicrobial activities of spinach leaf extracts were determined in order to evaluate the efficiency of extraction power of ultrasound. The results showed that the inhibitory zone diameters increased with the increasing power of ultrasound (Fig. 1 \& Fig. 2). When the extraction power was increased from 30 to $44 \%$, the inhibitory zone diameters (Fig. 1 \& Fig. 2) were increased for both $S$. aureus and E. coli. Disruption of the cell walls of the spinach leaves was increased when the extraction power was increased to an optimal condition. It was inferred that the solubility of the compounds was also increased (Ying et al. 2011) from higher yields. Increased inhibitory zone diameters suggest that the quality of the extract is increased. Furthermore, the vibration amplitude of sonication is closely associated with the intensity of ultrasound transmitted in the medium, thus the number of cavitation bubbles was increased. Therefore, both the extraction efficiency and quality of the active compounds was increased and enhanced (Dash et al. 2005).

\section{Effects of extraction times on bacterial growth}

The inhibitory zone diameters were increased when the duration of extraction was increased from 10 to 23 min but slowly decreased when the duration continued to be extended

314 (Fig. 1 \& Fig. 2). The zone of inhibition was predicted and it was found to be $24.95 \pm 0.10 \mathrm{~mm}$ and $20.93 \pm 0.13 \mathrm{~mm}$ for $S$. aureus and $E$. coli, respectively. This finding agreed with (Maran et al. 2013b) that showed the majority of phenolic compounds were released at the early period of extraction from broken cells. Moreover, the extension of the ultrasonic extraction time negatively affected the antimicrobial activity of spinach leaf extracts, probably due to the degradation of both pigments and polyphenols (Tiwari et al. 2009). The results obtained here are in accordance with published work Rostango et al. (2007), Showing that $20 \mathrm{~min}$ of sonication time was sufficient for extraction of phenolics from soy beverages.

\section{Determination and verification of models for ultrasonic parameters}

The suitability of the model equations for predicting optimal response values was tested under set conditions (extraction temperature of $45^{\circ} \mathrm{C}$, ultrasound power of $44 \%$ and extraction 
compare the experimental results with the predicted values of the responses. The experiments were conducted in triplicate and the average values were reported in Table 4 . The mean values of the zones of inhibition for $S$. aureus and $E$. coli obtained were compared with the predicted values. The experimental values were found to be in agreement with the predicted values and clearly indicated the suitability of the developed quadratic models.

\section{Determination of minimum inhibitory concentrations (MICs)}

According to the results shown in Figure 3, MIC was defined as the lowest concentration of the extract able to inhibit visible bacterial growth (Bonjar 2004; Prescott et al. 1999). The antibacterial activity of spinach leave extracts against $S$. aureus and E. coli was reflected in their respective Gram-negative and Gram-positive bacteria presented MIC values of $60 \mathrm{mg} / \mathrm{ml}$ and $70 \mathrm{mg} / \mathrm{ml}$, respectively. Thus, Gram-negative bacteria presented more susceptibility to plant extracts, and Gram-positive bacteria presented less susceptibility (Fig. 4). The antimicrobial activity of spinach extracts was compared to the standard antibiotic streptomycin. The results showed that streptomycin had higher antibacterial effect against all the bacterial strains tested as compared to the extracts (Fig. 4).

\section{Effects of the spinach leaf extracts on bacterial DNA}

In order to explore the genetic effects of the spinach leaf extracts in E. coli and S. aureus at the molecular level, the changes in the bacterial DNA due to the treatments employed were evaluated using RAPD marker analysis of genomic DNA. The RAPD results (Figure 5) showed polymorphism in the numbers and sizes of amplicons, among treated and non-treated bacteria. The highest number of polymorphic bands among treated $E$. coli was generated in reactions with the primers OPA-06 and OPB-06 (Table 5). That primer amplified four amplicons and represented $40 \%$ of the total bands. While, among treated S. aureus, the reaction with the primer OPB-06 resulted in the highest number of polymorphic bands (three) that represented 50\% of the total bands (Tables 5 and 6 ).

RAPD is a current and emerging technique employed to diagnostic mutation detection within a genome. The use of the RAPD assay for the detection of DNA damage and mutation changes has been extensively used in most kingdoms including plants (i.e. Alfalfa and Palmaria 
palmate), animals (i.e. Daphnia magna and Broiler chicken), and microorganisms (i.e. E. coli, Aeromonas hydrophila, and S. aureus) (Danylchenko and Sorochinsky, 2005, Atienzar et al., 2002a, Atienzar et al., 2002b, Ali, 2003). The results obtained from the current study suggest that spinach leaf extracts may induce mutations within bacterial genome. Therefore, RAPD analysis support the finding that spinach leave extracts exhibit antimicrobial activities on Gram-negative and Gram-positive food-borne pathogens. There were polymorphic banding patterns when comparisons were made between the non-treated bacteria and bacteria treated with different concentrations of the spinach leaf extracts (Figure 5).

Furthermore, it has been shown that molecular changes due to point mutations in plants which affect gene expression may cause an interruption in biochemical pathways of both DNA and protein synthesis (Lakhssassi et al., 2017a, Lakhssassi et al., 2017b). Such changes are inferred to be the result of secondary metabolism compounds, like alkaloids and phenols, which are contained in abundance in the spinach leaf extracts, as it has been previously reported by Adam et al. (2000), Morita et al. (2005), Gilani et al. (2007), and El-Tarras et al. (2013).. Therefore, spinach antimicrobial activities may be due also by the presence of compounds in spinach leaves and mechanism that could damage the cell wall via repression of gene expression or via restricting bacterial replication.

\section{Inhibition of bacterial growth by spinach leaf extracts}

SEM was used to examine possible morphological changes in the bacterial cells caused by spinach extracts. Treatment with spinach leaf extracts reduces dramatically the number of both $E$. coli and $S$. aureus; there are almost no bacteria in treated surfaces (Figure 6 and 7). In fact, lethal effects of high concentration from spinach leaf extracts on treated bacteria have been clearly observed. In the same way, it has been reported that oregano and thyme essential oils exhibit strong antimicrobial properties against $E$. coli $\mathrm{O} 157: \mathrm{H} 7$, in which the treated cells with essential oil were damaged, presenting similar effect on the cells (Burt and Reinders 2003). Burt (2004) suggested that the mechanism was due to the action of essential oil components in bacterial cells. The damage may be caused by direct damage to the cell wall or membrane proteins, causing cell lysis. 


\section{Conclusion}

In this study, RSM was used to optimize the conditions for ultrasound-assisted extraction of spinach leaves and to measure the antimicrobial activities of the prepared extracts. The results indicated that the temperature, power, and extraction time significantly affect the antimicrobial activities of the extracts. Preparation of extracts under optimal conditions increased the antimicrobial activity of the extracts, increased the size of the zone of inhibition of growth of treated bacteria compared to controls (non-treated bacteria). SEM images demonstrated that viable cell numbers was significantly reduced in bacterial cells treated with spinach leave extracts. Moreover, RAPD analysis of the genomic DNA showed that there were differences in the polymorphic bands between treated and non-treated bacteria ( $S$. aureus and E. coli). This data support the idea that DNA polymorphisms detected by RAPD is a powerful biomarker assay for detection of the level of DNA damage in treated $S$. aureus and E. coli strains by spinach leaf extracts, as it has been shown from previous studies (Danylchenko and Sorochinsky, 2005, Atienzar et al., 2002a, Atienzar et al., 2002b, Ali, 2013). Similar results were reported previously (El-Tarras et al. 2013) on the effect of Rhazya stricta leaf extracts and in two different studies with Conocarpus erectus and Moringa Peregrina (Hajar and Gumgumjee 2013). These findings lead us to conclude that ultra-sonicated spinach extracts can be effective antimicrobial agents against both Gram-negative and Gram-positive food-borne bacteria such as S. aureus and E. coli.

\section{Acknowledgements}

The authors would like to thank the Higher Committee for Education Development in Iraq (HCED) for the financial support to this work. Also, the authors are thankful to Dr. Alan Walters for providing spinach samples and Dr. Vjollca Konjufca for providing the bacterial strains and research facilities for the study.

\section{Author Contributions}

AA, designed, carried out and wrote the manuscript. DAL supervised; helped design the research; and proofread the article. NL. designed, analyzed, and carried out the RAPD experiments, edited drafts of the manuscript, AGA helped edit drafts of the manuscript. 


\section{Competing interests}

The authors declare they have no competing interests.

\section{Consent for publication}

413 Not applicable.

414 Ethics and consent to participate

415 This study did not involve humans, human data or animals; no ethics approval or consent is required to 416 publish the results.

417 References

Adam S, Al-Farhan A, Al-Yahya M (2000) Effect of combined Citrullus colocynthis and Rhazya stricta use in Najdi sheep. Am J Chin Med 28:385-390

Adeniran O, Olajide O, Igwemmar N, Orishadipe A (2013) Phytochemical constituents, antimicrobial and antioxidant potentials of tree spinach [Cnidoscolus aconitifolius (Miller) IM Johnston]. J Med Plant Res 7: 1310-1316

Ali BA (2003) Detection of DNA alteration in abnormal phenotype of broiler chicken male by random amplified polymorphic DNA (RAPD). Afr J Biotechnol 2: 153-156

Altemimi A, Choudhary R, Watson DG, Lightfoot DA (2015a) Effects of ultrasonic treatments on the polyphenol and antioxidant content of spinach extracts. Ultrason Sonochem 24: $247-255$

Altemimi A, Lightfoot DA, Kinsel M, Watson DG (2015b) Employing Response Surface Methodology for the Optimization of Ultrasound Assisted Extraction of Lutein and $\beta$ Carotene from Spinach. Molecules 20: 6611-6625

Altemimi A, Watson DG, Kinsel M, Lightfoot DA (2015c) Simultaneous extraction, optimization, and analysis of flavonoids and polyphenols from peach and pumpkin extracts using a TLC-densitometric method. Chem Cent Journal 9: 1-15 
Atienzar FA, Evenden AJ, Jha AN, Depledge MH (2002a) Use of the random amplified polymorphic DNA (RAPD) assay for the detection of DNA damage and mutations: possible implications of confounding factors. Biomarkers 7: 94-101.

Atienzar FA, Venier P, Jha AN, Depledge MH (2002b) Evaluation of the random amplified polymorphic DNA (RAPD) assay for the detection of DNA damage and mutations. Mutat Res Genet Toxicol Environ Mutagen 521: 151-163.

Bai X, Long J, He X, Li S, Xu H (2014) Molecular cloning and characterization of pathogenesisrelated protein family 10 gene from spinach (SoPR10). Biosci Biotechnol Biochem 78:780-786

Bauer A, Kirby W, Sherris JC, turck, Turck M (1966) Antibiotic susceptibility testing by a standardized single disk method. Am J Clin Pathol 45: 493

Bonjar GS (2004) Evaluation of antibacterial properties of Iranian medicinal plants against Micrococcus luteus, Serratia marcescens, Klebsiella pneumoniae and Bordetella bronchoseptica. Asian J Plant Sci 3: 82-86

Broekaert WF, Terras F, Cammue B, Osborn RW (1995) Plant defensins: novel antimicrobial peptides as components of the host defense system. Plant Physiol 108: 1353

Burt S (2004) Essential oils: their antibacterial properties and potential applications in foods-a review. Int J Food Microbiol 94: 223-253

Burt SA, Reinders RD (2003) Antibacterial activity of selected plant essential oils against Escherichia coli O157: H7. Lett Appl Microbiol 36: 162-167

Casal M, Vaquero M, Rinder H, Tortoli E, Grosset J, Rüsch-Gerdes S, Gutierrez J, Jarlier V (2005) A case-control study for multidrug-resistant tuberculosis: risk factors in four European countries. Microb Drug Resist 11: 62-67

Cevallos-Casals BA, Byrne D, Okie WR, Cisneros-Zevallos L (2006) Selecting new peach and plum genotypes rich in phenolic compounds and enhanced functional properties. Food Chem 96: 273-280

Chambers HF (2001) The changing epidemiology of Staphylococcus aureus? Emerg Infect Diseases 7: 178

Chopra I, Hodgson J, Metcalf B, Poste G (1996) New approaches to the control of infections caused by antibiotic-resistant bacteria: an industry perspective. J Am Med Assoc 275: $401-403$ 
Danylchenko O, Sorochinsky B (2005) Use of RAPD assay for the detection of mutation changes in plant DNA induced by UV-B and $\gamma$-rays. BMC Plant Biol 5: S9-S9

Dash K, Thangavel S, Krishnamurthy N, Rao S, Karunasagar D, Arunachalam J (2005) Ultrasound-assisted analyte extraction for the determination of sulfate and elemental sulfur in zinc sulfide by different liquid chromatography techniques. Anal. 130: 498-501

Diemert DJ (2006) Prevention and self-treatment of traveler's diarrhea. Clin Microbiol Rev 19: 583-594

El-Shemy HA, Aboul-Enein AM, Aboul-Enein KM, Fujita K (2007) Willow leaves' extracts contain anti-tumor agents effective against three cell types. Plos one 2:e178

El-Tarras AA, Hassan MM, El-Awady MA (2013) Evaluation of the genetic effects of the in vitro antimicrobial activities of Rhazya stricta leaf extract using molecular techniques and scanning electron microscope. Afr J Biotechnol 12: 3171-3180

Eloff J (1998) A sensitive and quick microplate method to determine the minimal inhibitory concentration of plant extracts for bacteria. Planta Med 64: 711-713

Faleiro L, Miguel G, Guerrero C, Brito J (1999) Antimicrobial activity of essential oils of rosmarinus officinalis, thymus mastichina. ssp mastichina and thymus albicans hofmanns e link Pharmacognosy. Acta Horticutlurae 501: 445-448

Ghafoor K, Choi YH, Jeon JY, Jo IH (2009) Optimization of ultrasound-assisted extraction of phenolic compounds, antioxidants, and anthocyanins from grape (Vitis vinifera) seeds. J Agric Food Chem 57: 4988-4994

Gil MI, Tomás-Barberán FA, Hess-Pierce B, Kader AA (2002) Antioxidant capacities, phenolic compounds, carotenoids, and vitamin $\mathrm{C}$ contents of nectarine, peach, and plum cultivars from California. J Agric Food Chem 50: 4976-4982

Gilani SA, Kikuchi A, Shinwari ZK, Khattak ZI, Watanabe KN (2007) Phytochemical, pharmacological and ethnobotanical studies of Rhazya stricta Decne. Phytother Res 21: 301-307

Hajar AS, Gumgumjee NM (2013) Antibacterial efficiency and DNA impairment unveil in some bacteria strains treated with Conocarpus erectus L. extract. Int J Appl Biol Pharm 4:3747 
Han SS, Seo HJ (2002) Articles: Curcumin Suppresses Activation of NF-kB and AP-1 Induced by Phorbol Ester in Cultured Human Promyelocytic Leukemia Cells. Mol Biol Rep 35: $337-342$

Lakhssassi N, Colantonio V, Flowers ND, Zhou Z, Henry J, Liu S, Meksem K (2017a) Stearoylacyl carrier protein desaturase mutations uncover an impact of stearic acid in leaf and nodule structure. Plant Physiol 174: 1531-1543

Lakhssassi N, Zhou Z, Liu S, Colantonio V, Abughazaleh A, Meksem K (2017b) Characterization of the FAD2 Gene Family in Soybean Reveals the Limitations of GelBased TILLING in Genes with High Copy Number. Front Plant Sci 8: 324

Maran JP, Manikandan S, Nivetha CV, Dinesh R (2013a) Ultrasound assisted extraction of bioactive compounds from Nephelium lappaceum L. fruit peel using central composite face centered response surface design. Arab J Chem 10: 1145-1157.

Maran JP, Mekala V, Manikandan S (2013b) Modeling and optimization of ultrasound-assisted extraction of polysaccharide from Cucurbita moschata. Carbohyd Polym 92: 2018-2026

Marathe NP, Rasane MH, Kumar H, Patwardhan AA, Shouche YS, Diwanay SS (2013) In vitro antibacterial activity of Tabernaemontana alternifolia (Roxb) stem bark aqueous extracts against clinical isolates of methicillin resistant Staphylococcus aureus. Ann Clin Microbiol Antimicrob 12: 26

Miyasaki Y, Nichols WS, Morgan MA, Kwan JA, Van Benschoten M, Kittell PE, Hardy WD (2010) Screening of herbal extracts against multi-drug resistant Acinetobacter baumannii. Phytother Res 24: 1202-1206

Morita H, Awang K, Hadi AHA, Takeya K, Itokawa H, Kobayashi Ji (2005) Conformational analysis of rhazinilam and three-dimensional quantitative structure-activity relationships of rhazinilam analogues. Bioorg Med Chem Lett 15: 1045-1050

Pedersen JR, Olsson JO (2003) Soxhlet extraction of acrylamide from potato chips. Anal 128: 332-334

Prescott M, Harley J, Donald P, Klein A (1999) In Antimicrobial chemotherapy Microbiology 2nd Edn published by C Brown Publishers USA

Prior RL, Cao G (2000) Antioxidant phytochemicals in fruits and vegetables: diet and health implications. HortScience 35: 588-592 
Rojas JJ, Ochoa VJ, Ocampo SA, Muñoz JF (2006) Screening for antimicrobial activity of ten medicinal plants used in Colombian folkloric medicine: A possible alternative in the treatment of non-nosocomial infections. BMC Complement Altern Med 6: 2

Rostagno MA, Palma M, Barroso CG (2007) Ultrasound-assisted extraction of isoflavones from soy beverages blended with fruit juices. Anal Chim Acta 597: 265-272

Sağdıç O, Kuşçu A, Özcan M, Özçelik S (2002) Effects of Turkish spice extracts at various concentrations on the growth of Escherichia coli O157: H7. Food Microbiol 19: 473-480

Sağdıç O, Özcan M (2003) Antibacterial activity of Turkish spice hydrosols. Food Control 14: $141-143$

Segura A, Moreno M, Molina A, García-Olmedo F (1998) Novel defensin subfamily from spinach (Spinacia oleracea). FEBS lett 435: 159-162

Shan B, Cai Y-Z, Brooks JD, Corke H (2007) The in vitro antibacterial activity of dietary spice and medicinal herb extracts. Int J Food Microbiol 117: 112-119

Singh P, Arnold R, Agnihotri S, Saxena A, Singh P, Tiwari S (2013) Optimization of antimicrobial activity of medicinal plants (Coriandrum sativum, Ocimum tenuiflorum and Phyllanthus emblica) against MDR pathogens. Int J Pharm Biol Sci 4: 2885-2889

Stotz HU, Thomson J, Wang Y (2009) Plant defensins: defense, development and application. Plant Signal Behav 4: 1010-1012

Tajkarimi M, Ibrahim S, Cliver D (2010) Antimicrobial herb and spice compounds in food. Food control 21: 1199-1218

Tegos G, Stermitz FR, Lomovskaya O, Lewis K (2002) Multidrug pump inhibitors uncover remarkable activity of plant antimicrobials. Antimicrob Agents Chemother 46: 31333141

Tiwari B, O'Donnell C, Cullen P (2009) Effect of sonication on retention of anthocyanins in blackberry juice. J Food Eng 93: 166-171

Vickers A (2002) Botanical medicines for the treatment of cancer: rationale, overview of current data, and methodological considerations for phase I and II trials. Cancer investigat 20: 1069-1079

Vinatoru M (2001) An overview of the ultrasonically assisted extraction of bioactive principles from herbs. Ultrason sonochem 8: 303-313 
Williams JG, Kubelik AR, Livak KJ, Rafalski JA, Tingey SV (1990) DNA polymorphisms amplified by arbitrary primers are useful as genetic markers. Nucleic acids res 18: 65316535

Xi J, Shouqin Z (2007) Antioxidant activity of ethanolic extracts of propolis by high hydrostatic pressure extraction. Food Sci Technol Int 42: 1350-1356

Yang B, Liu X, Gao Y (2009) Extraction optimization of bioactive compounds (crocin, geniposide and total phenolic compounds) from Gardenia (Gardenia jasminoides Ellis) fruits with response surface methodology. Innov food sci \& emerg technol 10: 610-615

Ying Z, Han X, Li J (2011) Ultrasound-assisted extraction of polysaccharides from mulberry leaves. Food Chem 127: 1273-1279

Yolmeh M, Habibi-Najafi MB, Shakouri S, Hosseini F (2014) Comparing Antibacterial and Antioxidant Activity of Annatto Dye Extracted by Conventional and Ultrasound-Assisted Methods. Zahedan J Res Med Sci 17: e1020

\section{Figure and Legends}

Figure 1: Response surface model plot showing the effects of independent variables on zone of inhibition (S.aureus). Panel (A) represent temperature and power. Panel (B) represent temperature and time. Panel (C) represent power and time.

Figure 2: Response surface model plot showing the effects of independent variables on zone of inhibition (E. coli). Panel (A) represent temperature and power. Panel (B) represent temperature and time. Panel $(\mathbf{C})$ represent power and time.

Figure 3: Micro-well plate assay for MIC under the optimized conditions. Twelve different concentrations have been tested.

Figure 4: Microbial growth inhibition by ultra-sonicated spinach extracts under the optimized conditions at $140 \mathrm{mg}$. (S) S.aureus, (E) E. coli.

Figure 5: RAPD profile of $S$. aureus and E. coli after the treatment with ultra-sonication of spinach extracts under the optimized conditions. CE: untreated $E$. coli; E: treated E. coli; CS: untreated S. aureus; S: treated S. aureus. OPA and OPB represent the three random primers used for RAPD fingerprinting of the treated and non-treated two bacterial isolates (see material and method for primer sequences). Arrows in the left side indicate the molecular size obtained after running the $1 \mathrm{~Kb}$ Plus DNA Ladder (thermofisher). 
591

592

593

594

595

596

597

598

599

600

601

Figure 6: Scanning electron micrographs of (A) untreated and (B) treated E. coli cells under the optimized conditions and $140 \mathrm{mg}$ of spinach extract.

Figure 7: Scanning electron micrographs of (A) untreated and (B) treated Staphylococcus aureus cells under the optimized conditions $140 \mathrm{mg}$ of spinach extracts.

\section{Tables}

Table 1. Codes of variables levels used in the experimental design for RSM ${ }^{\mathrm{a}}$.

\begin{tabular}{|c|c|c|c|c|}
\hline \multicolumn{3}{|c|}{ Independent variables } & \multicolumn{2}{l|}{ Zone of inhibition $(\mathrm{mm})$} \\
\hline Temp $\left(\mathrm{X}_{1}\right){ }^{\circ} \mathrm{C}$ & Power $\left(\mathrm{X}_{2}\right) \%$ & $\operatorname{Time}\left(\mathrm{X}_{3}\right) \min$ & S. aureus & E. coli \\
\hline 30 & 50 & 20 & 22 & 18.5 \\
\hline 40 & 50 & 30 & 25 & 21 \\
\hline 30 & 30 & 10 & 17 & 13 \\
\hline 50 & 30 & 30 & 22 & 18 \\
\hline 40 & 50 & 20 & 25 & 21 \\
\hline 40 & 50 & 20 & 24 & 20 \\
\hline 40 & 50 & 10 & 21 & 17 \\
\hline 30 & 70 & 10 & 17 & 13 \\
\hline 30 & 70 & 30 & 18 & 14 \\
\hline 30 & 30 & 30 & 19 & 18 \\
\hline 40 & 70 & 20 & 22 & 21 \\
\hline 40 & 50 & 20 & 25 & 20 \\
\hline 40 & 50 & 20 & 24 & 20.5 \\
\hline 40 & 50 & 20 & 25 & 17 \\
\hline 50 & 70 & 30 & 21 & 19 \\
\hline 40 & 30 & 20 & 23 & 19 \\
\hline 50 & 30 & 10 & 23 & 21 \\
\hline 40 & 50 & 20 & 25 & 16 \\
\hline 50 & 50 & 20 & 25 & 20 \\
\hline 50 & 70 & 10 & & \\
\hline
\end{tabular}


Table 2: Significance of the models.

\begin{tabular}{|c|c|c|c|c|c|c|}
\hline Source & $\begin{array}{l}\text { Sum of } \\
\text { squares }\end{array}$ & $\begin{array}{l}\text { Degree of } \\
\text { freedom }\end{array}$ & $\begin{array}{l}\text { Mean } \\
\text { square }\end{array}$ & F value & Prob $>F$ & Remarks \\
\hline \multicolumn{7}{|c|}{ Sequential model sum of squares for S.aureus } \\
\hline Mean & 9812.45 & 1 & 9812.45 & & & \\
\hline Linear & 40.9 & 3 & 13.63 & 2.10 & 0.1399 & \\
\hline Quadratic & 94.34 & 3 & 31.44 & 45.35 & $<0.0001$ & \\
\hline Cubic & 5.6 & 4 & 1.4 & 6.30 & 0.0244 & \\
\hline Residual & 1.33 & 6 & 0.222 & & & \\
\hline Total & 9957 & 20 & 497.85 & & & \\
\hline \multicolumn{7}{|c|}{ Sequential model sum of squares for $E$. coli } \\
\hline Mean & 6606.61 & 1 & 6606.61 & & & \\
\hline Linear & 38.75 & 3 & 12.92 & 2.06 & 0.1462 & \\
\hline Quadratic & 90.77 & 3 & 30.26 & 41.58 & $<0.0001$ & \\
\hline Cubic & 6.00 & 4 & 1.50 & 7.05 & 0.0188 & \\
\hline Residual & 1.28 & 6 & 0.21 & & & \\
\hline \multicolumn{7}{|c|}{ Model summary statistics } \\
\hline Source & Std. Dev. & $\mathrm{R}^{2}$ & Adjusted $\mathrm{R}^{2}$ & \multicolumn{2}{|c|}{ PRESS } & Remarks \\
\hline \multicolumn{7}{|c|}{ Model summary statistics for S.aureus } \\
\hline Linear & 2.55 & 0.2829 & 0.1485 & \multicolumn{2}{|c|}{187.05} & \\
\hline Quadratic & 0.83 & 0.9520 & 0.92 & \multicolumn{2}{|c|}{62.76} & \\
\hline Cubic & 0.47 & 0.9908 & 0.90 & \multicolumn{2}{|c|}{2.65} & \\
\hline \multicolumn{7}{|c|}{ Model summary statistics for $E$. coli } \\
\hline Linear & 2.50 & 0.2785 & 0.1432 & \multicolumn{2}{|c|}{182.34} & \\
\hline Quadratic & 0.85 & 0.9477 & 0.912 & \multicolumn{2}{|c|}{72.33} & \\
\hline Cubic & 0.46 & 0.9908 & 0.909 & \multicolumn{2}{|c|}{85.56} & \\
\hline
\end{tabular}


617 Table 3: Analysis of variance for the fitted second order polynomial models.

\begin{tabular}{|c|c|c|c|c|c|c|}
\hline Source & $\begin{array}{l}\text { Coefficient } \\
\text { estimate }\end{array}$ & $\begin{array}{l}\text { Degree of } \\
\text { freedom }\end{array}$ & Sum of square & Mean square & F-value & p-value \\
\hline \multicolumn{7}{|l|}{ S. aureus } \\
\hline Model & 24.67 & 9 & 137.62 & 15.29 & 22.05 & $<0.0001$ \\
\hline $\mathrm{X}_{1}$ & 1.80 & 1 & 32.40 & 32.40 & 46.73 & $<0.0001$ \\
\hline $\mathrm{X}_{2}$ & -0.60 & 1 & 3.60 & 3.60 & 5.19 & 0.0459 \\
\hline $\mathrm{X}_{3}$ & 0.70 & 1 & 4.90 & 4.90 & 7.07 & 0.0240 \\
\hline $\mathrm{X}_{1} \mathrm{X}_{2}$ & -0.37 & 1 & 1.12 & 1.12 & 1.62 & 0.2316 \\
\hline $\mathrm{X}_{1} \mathrm{X}_{3}$ & -0.37 & 1 & 1.12 & 1.12 & 1.62 & 0.2316 \\
\hline $\mathrm{X}_{2} \mathrm{X}_{3}$ & 0.13 & 1 & 0.13 & 0.13 & 0.18 & 0.6801 \\
\hline $\mathrm{X}_{1}^{2}$ & -1.18 & 1 & 3.84 & 3.84 & 5.54 & 0.0404 \\
\hline $\mathrm{X}_{2}^{2}$ & -2.18 & 1 & 13.09 & 13.09 & 18.88 & 0.0015 \\
\hline $\mathrm{X}_{3}^{2}$ & -1.68 & 1 & 7.78 & 7.78 & 11.22 & 0.0074 \\
\hline \multicolumn{2}{|l|}{ Lack of fit } & 5 & 5.60 & 1.12 & 4.20 & 0.0706 \\
\hline \multicolumn{7}{|l|}{ C.V\% 3.76} \\
\hline \multicolumn{7}{|l|}{ E. coli } \\
\hline Model & & 9 & 131.86 & 14.65 & 20.13 & $<0.0001$ \\
\hline $\mathrm{X}_{1}$ & & 1 & 28.90 & 28.90 & 39.72 & $<0.0001$ \\
\hline $\mathrm{X}_{2}$ & & 1 & 4.23 & 4.23 & 5.81 & 0.0367 \\
\hline $\mathrm{X}_{3}$ & & 1 & 5.62 & 5.62 & 7.73 & 0.0194 \\
\hline $\mathrm{X}_{1} \mathrm{X}_{2}$ & & 1 & 0.78 & 0.78 & 1.07 & 0.3245 \\
\hline $\mathrm{X}_{1} \mathrm{X}_{3}$ & & 1 & 1.53 & 1.53 & 2.10 & 0.1775 \\
\hline $\mathrm{X}_{2} \mathrm{X}_{3}$ & & 1 & 0.031 & 0.031 & 0.043 & 0.8400 \\
\hline$X_{1}^{2}$ & & 1 & 2.63 & 2.63 & 3.61 & 0.0866 \\
\hline $\mathrm{X}_{2}^{2}$ & & 1 & 13.64 & 13.64 & 18.75 & 0.0015 \\
\hline$X_{3}^{2}$ & & 1 & 8.20 & 8.20 & 11.28 & 0.0073 \\
\hline \multicolumn{2}{|l|}{ Lack of fit } & 5 & 6.07 & 1.21 & 5.02 & 0.0505 \\
\hline
\end{tabular}



conditions and the modified optimal extraction conditions

\begin{tabular}{|c|c|c|c|c|c|}
\hline \multirow{2}{*}{ Name } & \multicolumn{3}{|c|}{ Extraction variables } & \multirow{2}{*}{ S. aureus } & \multirow{2}{*}{ E. coli } \\
\cline { 2 - 6 } & $\mathrm{X}_{1}(\mathrm{C})$ & $\mathrm{X}_{2}(\%)$ & $\mathrm{X}_{3}(\mathrm{~min})$ & & 21.08 \\
\hline Optimum conditions( predicted) & 44.40 & 43.37 & 22.71 & 25.10 & $20.93 \pm 0.125$ \\
\hline $\begin{array}{c}\text { Modified optimal condition } \\
\text { (experimental values) }\end{array}$ & 45 & 44 & 23 & $24.95 \pm 0.100$ & \\
\hline
\end{tabular}

*Mean \pm standard deviation $(\mathrm{n}=3)$.

629

630

631

632

633

634

635

636

637

638

639

640

641

642

643 
647 Table 5: Polymorphic bands of each genetic primers and percentage of polymorphism in E. coli treated 648 with different concentration of spinach leave extracts.

649

\begin{tabular}{|c|c|c|c|c|c|}
\hline E. coli & Total & $\begin{array}{c}\text { Number of } \\
\text { monomorphic } \\
\text { Primers }\end{array}$ & $\begin{array}{c}\text { Number } \\
\text { bolymorphic } \\
\text { band }\end{array}$ & $\begin{array}{c}\text { Percentage } \\
\text { Monomorphic } \\
\text { band }\end{array}$ & $\begin{array}{c}\text { Percentage } \\
\text { Polymorphic } \\
\text { band }\end{array}$ \\
\hline OPA-05 & 10 & 6 & 4 & $60 \%$ & $40 \%$ \\
\hline OPA-06 & 7 & 4 & 3 & $57.14 \%$ & $42.80 \%$ \\
\hline OPB-06 & 7 & 4 & 3 & $57.14 \%$ & $42.80 \%$ \\
\hline Total & 24 & 14 & 10 & - & - \\
\hline
\end{tabular}

650

651

652

653

654

655

656

657

658

659

660

661

662

663

664

665 
669 Table 6: Polymorphic bands of each genetic primers and percentage of polymorphism in $S$. Aureus 670 treated with different concentration of spinach leave extracts.

671

\begin{tabular}{|c|c|c|c|c|c|}
\hline S. Aureus & Total & $\begin{array}{c}\text { Number of } \\
\text { monomorphic } \\
\text { Brimers }\end{array}$ & $\begin{array}{c}\text { Number } \\
\text { polymorphic } \\
\text { band }\end{array}$ & $\begin{array}{c}\text { Percentage } \\
\text { Monomorphic } \\
\text { band }\end{array}$ & $\begin{array}{c}\text { Percentage } \\
\text { Polymorphic } \\
\text { band }\end{array}$ \\
\hline OPA-05 & 6 & 4 & 2 & $66.66 \%$ & $33.33 \%$ \\
\hline OPA-06 & 7 & 4 & 3 & $57.14 \%$ & $42.80 \%$ \\
\hline OPB-06 & 6 & 3 & 3 & $50.00 \%$ & $50.00 \%$ \\
\hline Total & 19 & 11 & 8 & - & - \\
\hline
\end{tabular}

672

673 